\title{
Student Attitude to Internet Resources of Charitable Subjects
}

\author{
Denis G. Shelevoi \\ Pacific National University, Russia \\ ORCID: 0000-0003-0568-3261 \\ Alexander V. Ostroushko \\ Financial University Under the Government of the Russian Federation, Russia \\ ORCID: 0000-0003-0595-9205 \\ Olga A. Pervozvanskaya \\ Gzhel State University, Russia \\ ORCID: 0000-0002-2190-707X \\ Yuliya L. Kamasheva \\ Kazan Innovative University named after V. G. Timiryasov, Russia \\ ORCID: 0000-0002-7695-0155 \\ Jhanna I. Aytuganova \\ Kazan State Power Engineering University, Russia \\ ORCID: 0000-0003-3505-401X \\ Andrey V. Kazakov \\ Vyatka State University, Russia \\ ORCID: 0000-0001-5522-4624
}

\begin{abstract}
This article is aimed at assessing the attitudes and characteristics of students' use of Internet resources for charitable activities. Modern society is considered as informational - fully permeated with information and communication processes, implemented not only in real but also in a virtual environment. The article investigates the development of charity in the modern information society. The aim of the research is to study the attitude of students to Internet resources as a tool for the development of charity in Russia. The research methods is the analysis based on the use of methods of content analysis and General scientific empirical research methods to identify the characteristics of students' attitude to the Internet resources of charitable subjects. The article considers the concept of charity as a process aimed at changing, improving the qualitative and quantitative characteristics of charitable activities. It is established that the qualitative characteristics of charitable activities are sincerity and targeting of assistance; perception of the concept of charity; quantitative characteristics of charity are the activity of charitable assistance (the volume of its implementation); coverage of those in need of charitable assistance; frequency of charitable assistance (how often a person provides assistance). The results of the evaluation of students' attitude to the Internet resources of charitable subjects shows that at the moment the Internet resources of charitable subjects only half correspond to the qualitative and quantitative characteristics of the development of charitable activities, but in solving certain problems, this coverage can be absolute, which allows us to consider Internet resources as possible tools for the development of charitable activities. The necessity of creating an emotional component in the process of expressing gratitude to the benefactor
\end{abstract}




\begin{abstract}
is revealed (the Internet resource should always personally thank the user for the assistance provided; Internet resources are offered to focus more on the targeting and efficiency of assistance). The novelty and originality of the study lies in the fact that the quantitative and qualitative characteristics of charitable assistance are determined. The features of the attitude of students to the Internet resources of charitable subjects are revealed. The analysis revealed that the main problem of using Internet resources for charity was the distrust of Internet users. The principles for work of Internet resources of charitable subjects in work with philanthropists are defined: the principle of targeting, which means that the activity of the Internet resource is aimed at assisting a certain category of people in need; the principle of efficiency in the activities of Internet resources should mean that the administration of user interaction should be carried out as quickly as possible.
\end{abstract}

Keywords: student youth, online resources, charity

\title{
INTRODUCTION
}

Charitable activity is a voluntary process of search and redistribution of material and nonmaterial resources from individuals and organizations, without the prospect of improving their own well-being at this expense, but provided that it does not harm other people and is carried out within the framework of the law, benefits not only the recipients of benefits, but also society as a whole, removing from it part of social obligations. Hence, charity includes such acts, which in the conventional sense of the word fit into the concept of public benefit, consisting in individual assistance to a particular person, which is beneficial to society as a whole (Alisov et al., 2018; Badya, 1993; Benzin, 1906; Kalugina \& Tarasevich, 2018; Lykoshina, 1901; Maximov, 1895, 1903; Selivanov, 1910; Sokolovsky, 2006; Vasbieva \& Kalugina, 2016).

The main differences among researchers and scientists are not only in the specific views on the essence of the phenomenon, but also in the specific allocation of the subject and object of charity (Firsov, 2000; Klyuchevsky, 2008; Model \& Model, 2002; Zelikova, 2003).

The analysis of approaches to the definition of charity shows that among researchers there is no common understanding of the essence of the phenomenon. On the one hand, there is a unanimous recognition that charity is a free aid to the needy. On the other hand, there is no single idea about what kind of assistance should be attributed to charity, who is the subject and object of charity, what are the place and functions of charity in society (Ershova, 2015; Karagodina, 2015; Lafargue, 1988; Mandeville, 1974; Sokolov, 2006).

The traditional typology of charity in modern conditions includes various classifications of charitable activity, defined by: the used resources of charity; the purposes of charitable activity; forms of participation.

Vasilyeva (2012) offers to understand the financial charity as cash assistance from the funds of the organization and cash donations which are sent free of charge from the donor (the citizen) to the recipient; material charity - the donation of products (services) by enterprises, financial donations to the needy in the form of clothing, food items; under organizational charity provision of consulting services (information, special - consultations of a psychologist, lawyer, etc., preparation and implementation of targeted social programs in the field of charity (Vasilyeva, 2012).

The typological feature of charitable activity is its goals. At the present stage of development of the Russian state, the goals of charity as a social institution are specified by the legislation, and 
are reflected in the works of many researchers. Among the main goals of charity, which are covered by the Federal law, we can note the following:

- social support and protection of citizens, including the improvement of the financial situation of the poor, social rehabilitation of the unemployed, disabled and other persons who due to their physical or intellectual characteristics, other circumstances are unable to independently exercise their rights and legitimate interests;

- preparation of the population to overcome the consequences of natural disasters, environmental, industrial or other disasters, to prevent accidents;

- assistance to victims of natural disasters, environmental, industrial or other disasters; social, national, religious conflicts, as well as victims of repression, refugees and internally displaced persons;

- Promotion of peace, friendship and harmony among peoples, prevention of social, national and religious conflicts, etc.

Charity allows society to serve its interests directly, without the mediation of the state, ensuring the redistribution of income from the most haves to the least haves' citizens (Vdovin, 2012).

Another typological feature is the form of participation in charitable activities. Tolkova (2013) believes that depending on the nature of participation (direct actions to provide assistance are the following types of charity: volunteering - voluntary social activities (activities for mutual assistance and self-help, the official provision of services and other forms of civic participation, which is carried out for the benefit of the General public without the calculation of monetary compensation); donation - voluntary payment without coercion, gratuitous gift, transfer of money in favor of any organization or person (Tolkova, 2013). In addition, in the scientific literature there are other classifications of types of charity. The object of activity: children (4-14 years); youth (14-30 years); Mature (30-50 years); pension (people of retirement age); inclusive (people with disabilities). In Russia, youth volunteering, which also receives state support, is becoming the most widespread. Young people are actively engaged by voluntary organizations to work with children in various fields, especially in hospitals and orphanages, to solve environmental problems of local importance and to organize cultural events. The second quantitative coverage of object is a mature volunteer, then as a child, and inclusive pension in Russia is practically not represented, as children, the elderly and persons with disabilities are only viewed as objects of care.

By duration: A) single; B) event; C) regular. Every person at least once in his/her life volunteered to perform work that was not related to his/her professional work and has a selfless character. This response, as a rule, is an emotional reaction to the event that shocked the individual and may not happen again in the future. Event charity is associated with the participation of the subject of activity in any actions and charity events that are carried out periodically and do not require permanent employment.

We should also pay attention to the mechanisms of charity. In Russia, there have long been various social mechanisms for the formation of charity, corresponding to the spheres of activity: economic, political, spiritual. Social mechanisms of formation of charity - a set of means by which the regulation of social relations in the field of charity is fulfilled; social system, the mechanism that determines the order of the organization of charitable activities. Economic mechanisms of the formation of the charity were intended to doing charity work, which was profitable. Political mechanisms for the formation of charity acted in such a way that it helped to retain power or to join those in power. According to the researchers here, we could talk about the presence of 
role structures that carry out charity, contribute to charity (Tyutchenko \& Fisenko, 2015). Spiritual formation mechanisms of philanthropy is ideological, moral, psychological, religious feelings, attitudes (Cherdymova et al., 2018, 2019a, 2019b; Sorokoumova et al., 2019; Telnykh \& Shakhnazaryan, 2016; Tyutchenko \& Fisenko, 2015; Vasbieva et al., 2018).

\section{MATERIALS AND METHODS}

For the best understanding of the situation related to the development of charity in the Internet, we should pay special attention to those sites that are most visible on the Internet as active philanthropists and organizers of charity. To study the sector of charitable sites we are interested in, we: selected the most active sites engaged in charitable activities on the Internet; described the specifics of different types of Internet resources of charitable subjects on the basis of content analysis, conducted a typology of these resources; revealed the attitude of students to the Internet resources of charitable subjects.

The target sample was made up of Russian-language Internet sites, blogs, and forums of charitable subjects occupying a leading position in the search engine "Yandex" at the request of "charitable organizations". With regard to the Internet resources of charitable organizations, an analysis of their functionality was carried out. The choice of virtual groups of social network "Vkontakte" for comparative analysis was carried out spontaneously. The choice of virtual groups for comparative analysis was carried out on the basis of the following information: the presence on the website of information about the activities of the organization; the availability of information about the needs with a full description of the problems (current and already solved); the availability of financial assistance online; the availability of online opportunities to join the organization as a volunteer. These principles cover various essential features of Internet resources and their main purpose, which suggests the rationality of the analysis and its focus.

\section{RESULTS}

Among the most visited sites are the following: Fund for the protection of abandoned babies I am without a mother; Charity Foundation Help the children; the Charity Fund Gift of life; the Charity Fund Creation; the Charity Fund Happy world; the Charity Fund Life Line.

In order to better understand the problems and peculiarities of attracting Internet users to charitable activities, a survey was conducted in the form of a questionnaire.

The purpose of the survey was to determine how ordinary students-users of the social network "Vkontakte" refer to charity on the Internet and Internet resources on which it, one way or another, is carried out.

Having allocated the issue of anonymity and some distrust of students to online charity (for fear of fraud, lack of interpersonal contact), as the main reference point of the survey, we highlighted the problem of trust of students-users of Internet resources to charity, because it is on how much the user trusts the applicant (or organization), will depend on how easy it is to attract $\mathrm{him} /$ her to charity. Moreover, it will help to understand what problems prevent people from engaging in charitable activities through Internet resources.

In the empirical study, we set the following tasks:

- To study the attitude of students to charity outside the Internet space. 
- To identify the awareness of students about forms of charitable activities; opportunities to participate in organized charitable activities; involvement in organized charitable activities.

- To determine the students' interpretation of the goals of charitable activities;

- To study the respondents' perception of the effectiveness of charitable activities.

- To determine the involvement of students in organized charitable activities using Internet resources.

- To identify the awareness of students about the functioning of specific Internet resources of charitable subjects on the Internet.

- To identify the awareness of students about the availability of Internet resources of charitable subjects;

- To identify the awareness of students about the possibilities of participation in organized charity activities using Internet resources;

- To describe the degree of involvement of students in charitable activities on the Internet

The vast majority of the surveyed students visit the social network Vkontakte several times a day, $13 \%$ - once a day and only $7 \%$ several times a week (5\%) and less (4\%), which indicates a high level of popularity of this social network among students.

The nature of user activity in the network Vkontakte is mainly determined by such actions as conduct of personal correspondence $-819 \%$, viewing news $-52 \%$. Only $19 \%$ take part in public discussions and blog on the personal page of $18 \%$ of students.

Speaking about the forms of charity (as a factor of awareness of charitable activities), according to students, the most important are: financial assistance $-52 \%$ of respondents' answers, the Second popular answer - professional assistance $47 \%$ of answers. The third popular answer is $46 \%$ information assistance.

On the question of "What problems charity solves" (studying the respondents' understanding of the goals to charity), students answered as follows: $71 \%$, believes that charity brings people together, allows them to help each other- this answer has become the most popular in the choice of respondents, the Remaining answers were noted much less often: allows people to feel protected $-12 \%$, reduces tensions in society $-19 \%$, helps to improve the standard of living - $15 \%$, helps to find like - minded people- $18 \%$.

Most survey participants, 75\% of respondents, speaking about the effectiveness of charity, believe that charity to a small extent solves people's problems. Indicated a slight degree of efficiency - 23\%. Seven\% noted a significant degree of efficiency. The most popular were: $71 \%$ of the sites of the official funds of assistance to respondents were the charitable Foundation gift of life. Pages in social networks: group of assistance to the non-profit shelter Participation - $23 \%$. Personal Internet pages in need of assistance - $15 \%$. Among blogs: blogs on the site Echo of Moscow-12\%. Forums that are not presented in the proposed list - $9 \%$. Do not know any Internet resources $-17 \%$.

Among those respondents who had ever-charitable aid with the use of Internet resources, most of it provided financial aid - $84 \%$. In second place is information assistance - $31 \%$, in third place - moral assistance - $18 \%$. Also, respondents provided organizational $-14 \%$, spiritual $-13 \%$ and professional assistance - $11 \%$. 


\section{DISCUSSIONS}

Based on the conducted research and survey, we can state the peculiarities of attracting Internet users to charity and the problems of attracting. The features include the following. The simplicity and efficiency of care. In order to take part in charitable activities, the Internet user just visit the appropriate Internet resource and press a few buttons. Moreover, charitable activities are actively developing on those resources that are universal in terms of topics (social networks, blogs, etc.).) According to the received answers, various Internet resources of charitable subjects are quite well known to users of the social network Vkontakte. This means that the user of such a resource does not even need to move to another special resource and break away from his/her occupation - he/she can make a repost, comment on the message or write down the account number for the transfer of funds to the applicant. Organizations to search for donors actively penetrate into their social environment, the sphere of interests, and already in this environment organize an information campaign to highlight the problem of the needy.

Opportunity to demonstrate participation in charitable activities. Each person who provides assistance do so for a variety of reasons: he / she may sincerely wish to help, being impressed by the problem; he / she may do so autonomously, that is, make an alienated click on the payment button, without thinking much about the role of his / her assistance due to the simplicity of its provision, etc. Regardless of the reasons for providing assistance, the user can demonstrate the fact of its provision to their friends, using the function of repost information message to social networks, thereby "increasing their social status of virtue" in the eyes of others, which, in our opinion, should not be considered as a sincere desire to help, but also such assistance is important in terms of informing the public about the existence of a life problem in a particular subject. Internet resources of charitable subjects, introducing on their sites the appropriate functions and even offering to use them, actively use this.

High activity of scammers. This problem follows from the previous one. The presence of an anonymous aspect of interaction between users of Internet resources contributes to the development of fraud in the field of charity, the cases of which are regularly disclosed and covered in the press, on the same Internet resources.

The lack of reciprocal emotional contact. When the subject of charitable activities provides assistance directly, he/she sees the one who helps, observes his/her emotions and thus fully realizes the importance of his/her act. He/she hears words of gratitude, which are psychologically perceived more vividly than the text on the computer screen "Thank you for your help!" as a result, a significant proportion of students prefer to provide assistance outside the Internet.

Thus, despite the positive attitude of users of the social network Vkontakte to charity, a high level of understanding of the problems that helps to solve charity, awareness of the most important ways to solve social problems, readiness to provide assistance, their high user activity.

\section{CONCLUSION}

The analysis of approaches to the definition of charity has shown that among researchers there is no common understanding of the essence of the phenomenon. On the one hand, there is a unanimous recognition that charity is a free aid to the needy. On the other hand, there is no single idea of what kind of assistance should be attributed to charity, who is the subject and object of charity, what are the place and functions of charity in society. At the same time, the essential features of charity as a socio-cultural phenomenon suggest that the further development of charitable activities in Russia should take into account the historical experience 
of the development of the relevant concept and the search for new forms and means of communication that can bring charitable assistance to a more global level. Among the problematic aspects of attracting Internet users to charitable Internet resources were the problem of anonymity, high activity of fraudsters, and the lack of reverse emotional contact. Despite the positive attitude of users of the social network Vkontakte, a high level of understanding of the problems that helps to solve charity, awareness of the most important ways to solve social problems, readiness to provide assistance, their high user activity.

In our opinion, the development of charity is a process aimed at increasing the activity of charitable activities, increasing the coverage of those in need and increasing the frequency of charitable assistance, in the context of which an important role is played by the targeting of assistance, the sincerity of the philanthropist and his/her perception of the concept of charity as an important phenomenon in modern society. The development of the use of Internet resources by users of charitable subjects should include regional differentiation of the activities of Internet resources; development of internal anti-fraud policy; creation of an emotional component in gratitude to the subjects of assistance; focus on the targeting and efficiency of charitable assistance and the need to develop the educational direction of social volunteering.

\section{REFERENCES}

Alisov, E. A., Cherdymova, E. I., Trubina, G. F., Yakushev, A. N., Zhdanov, S. P., Popova, O. V., Kobzar-Frolova, M. N. (2018). Study of Dominant Type of Student Ecological Focus. Ekoloji, 27(106), 357-362.

Badya, L. V. (1993). Charity and philanthropy in Russia. Moscow: Historical Sciences.

Benzin, V. M. (1906). Parish charity in Russia. Labor assistance. Moscow.

Cherdymova, E. I., Afanasjeva, S. A., Parkhomenko, A. G., Ponyavina, M. B., Yulova, E. S., Nesmeianova, I. A., \& Skutelnik, O. A. (2018). Student ecological consciousness as determining component of ecological-oriented activity. Eurasian Journal of Biosciences, 12(2), 167-174.

Cherdymova, E. I., Ilkevich, T. G., Spirina, E. V., Blinov, L. V., Aliyev, H. K., Kukhtyaeva, E. A., \& Ivanshina, I. A. (2019a). Physicality Ecology: Student Attitude to Their Own Body. Ekoloji 28(107), 4925-4930.

Cherdymova, E. I., Prokopyev, A. I., Karpenkova, T. V., Pravkin, S. A., Ponomareva, N. S., Kanyaeva, O. M., Ryazapova, L. Z. \& Anufriev, A. F. (2019b). EcoArt Therapy as a Factor of Students' Environmental Consciousness Development. Ekoloji, 28(107), 687-693.

Ershova, N. M. (2015). Formation and development of charity in modern Russian society. Actual problems of Humanities and natural Sciences, 4, 30-35.

Firsov, M. V. (2000). Social charity: reality of time. SOCIS, 2, 54-62.

Kalugina, O. A., \& Tarasevich, N. A. (2018). Smart technology integration into EFL teaching at the $\begin{array}{llll}\text { non-linguistic higher school. } \quad \text { XLinguae, } & 11(1 \mathrm{XL}),\end{array}$ https://doi.org/10.18355/XL.2018.11.01XL.02

Karagodina, O. A. (2015). Social and philosophical aspects of Russian charity. Science, technology, innovation in the modern world, 1, 71-84.

Klyuchevsky, V. O. (2008). Good people of Ancient Russia. Moscow: Yauza. 
Lafargue, P. O. (1988). Charity. Ethical thought. Moscow: Scientific reading.

Lykoshina, P. I. (1901). Charitable Russia: history of state, public and private charity in Russia, Vol. 1. - Part 1. St. Petersburg.

Mandeville, B. (1974). An essay on charity and charity schools. The fable of the bees. Moscow: Mysl.

Maximov, E. D. (1895). Essay of Zemstvo activity in the field of public charity. St. Petersburg: Not.

Maximov, E. D. (1903). Special charitable departments and institutions. St. Petersburg: Not.

Model, I. M. \& Model, B. S. (2002). Charitable public associations in the institutional field of civil society. Scientific Yearbook of philosophy and law Institute of the Ural branch of the Russian Academy of Sciences, 3, 128-143.

Selivanov, A. F. (1910). Current state of Russian charity (speech at the I-st all-Russian Congress of public and private charity). Moscow: Proceedings of the first congress of Russian leaders in public and private charity.

Sokolov, A. R. (2006). Charity in Russia as a mechanism of interaction between society and the state (beginning of XVIII - end of XIX centuries). St. Petersburg: Faces of Russia.

Sokolovsky, M. K. (2006). On the issue of charity in Russia in the XVIII century. Labor assistance, $10,12-22$.

Sorokoumova, E. A., Cherdymova, E. I., Rezvantseva, M. O., Kochneva, L. V., Latysheva, V. V. \& Perkova, E. P. (2019). Environmental and Social Practices of Old Stuff Use and Disposal by Students. Ekoloji, 28(107), 5065-5069.

Telnykh, V. S., \& Shakhnazaryan, B. A. (2016). Main problems of charity in Russia and ways to solve them. Tauride scientific observer, 1, 7-11.

Tolkova, M. L. (2013). Images of charity in modern information field. News of Russian state pedagogical University named after A.I. Herzen, 162, 153-164.

Tyutchenko, A. M., \& Fisenko, O. S. (2015). Charity and social mechanisms of its formation. Topical issues of social and psychological research. Moscow: Collection of scientific and educational-methodic articles.

Vasbieva, D. G., \& Kalugina, O. A. (2016). An Analysis of Students' Intercultural Competence Levels in a Non-Linguistic Higher School. XLinguae, 9(3), 58-69. https://doi.org/10.18355/XL.2016.09.58-69

Vasbieva, D. G., Sokolova, N. L., Masalimova, A. R., Shinkaruk, V. M., \& Kiva-Khamzina, Y. L. (2018). Exploring the EFL teacher's role in a smart learning environment - a review study. XLinguae, 11(2), 265-274. https://doi.org/10.18355/XL.2018.11.02.21

Vasilyeva, E. G. (2012). Institutional charity: structure and mechanisms of implementation. Volgograd state socio-pedagogical University, 5, 82-95.

Vdovin, A. A. (2012). Russian charity as an object of state regulation. Labor and social relations, $11,41-57$. 
Zelikova, J. A. (2003). Women in charity organizations of St. Petersburg: motivation of participation. Gender dimension of social and political activity in transition. St. Petersburg: Europe. University in St. Petersburg.

Correspondence: Denis G. Shelevoi, Department of Economics and Management in Construction, Pacific National University, Khabarovsk, Russia. E-mail: dshel@yandex.ru 